\title{
Organic Matter Decomposition and Nutrient Release from Different Dhaincha (Sesbania spp.) Genotypes
}

\author{
Sontosh Chandra Chanda ${ }^{1,2}$, M. Rafiqul Islam ${ }^{3}$ and A.K.M. Golam Sarwar ${ }^{*}$
}

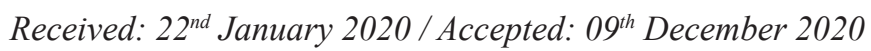

\begin{abstract}
Purpose: An experiment was conducted at Field Laboratory of the Department of Crop Botany, Bangladesh Agricultural University during April to July 2018 to compare the biomass yield potential, decomposition and nutrients release pattern of different dhaincha genotypes.

Research Method: Six dhaincha accessions from three Sesbania species, viz. S. bispinosa (accession \#05, 71, 77 and 109), S. cannabina (accession \#28) and S. sesbsan (accession \#81), were used as experimental materials. Dhaincha was cultivated with standard cultivation procedure following a randomized complete block design with three replications and incorporated with soil at 60 days after sowing.

Findings: There are wide variations in biomass yield, crude fibre and crude protein among the accessions. The amount of crude fibre may be used as a descriptor of taxonomic importance. Accession \#28 (S. cannabina) produced a significantly higher amount of crude fibre compared to other accessions. Soil organic matter (SOM) and nutrient elements availability increased with the period of time and reached to a peak at 50 days after biomass incorporation (DAI) except $K$ and $S$. The highest amount of SOM and $N$ was recorded in accession $\# 71$ and the lowest in accession \#81. The maximum amount of phosphorus and potassium was added by accession \#05 and the minimum phosphorus and potassium by accession \#28 and \#81, respectively. The greatest amount of sulfur showed 5.25 ppm in accession \#05 at 20 DAI and the smallest value 2.22 ppm in accession \#28 at 60 DAI.
\end{abstract}

Originality: It is evident from results that accession \#71 can be recommended for cultivation in the farmer's field for higher biomass yield and the maximum amount of nutrients release.

Keywords: Biochemical composition, Biomass yield, Sesbania, Soil nutrient status

\section{INTRODUCTION}

Soil organic matter releases nutrients for plants through the process of mineralization. Soil organic matter increases soil aeration, retention of moisture, $\mathrm{pH}$, buffering capacity and cation exchange capacity of soils. The balance amount of organic matter in soil depends on additions and the rate of decomposition of green manure, crop residues, etc. In Bangladesh, soil organic matter is depleting over a period of time (Ali et al., 1997; Zahid et al., 2011) in highland to medium highland soils due to intensive crop cultivation, imbalanced use of chemical fertilizers, continuous mono-crop culture and less use of green manure crops cultivation. Addition of crop/plant residues, compost or green manure has become a pivotal strategy for soil fertility improvement and sustainability of land use (Swarup, 1998). Soil fertility and productivity as well as higher soil organic matter can be improved through long term green manure crop cultivation (Carroll and

\footnotetext{
${ }^{1}$ Laboratory of Plant Systematics, Department of Crop Botany, Bangladesh Agricultural University, Mymensingh 2202, Bangladesh drsarwar@bau.edu.bd

${ }^{2}$ Present address - Additional Deputy Director (PP), Department of Agriculture Extension, Khamar Bari, Sirajganj, Bangladesh

${ }^{3}$ Department of Soil Science, Bangladesh Agricultural University, Mymensingh 2202, Bangladesh

DORCID http://orcid.org/0000-0003-0047-3943
} 
Somerville, 2009). The effect of decomposition of a green manure crop can be largely attributed to the increase of plant nutrients availability in soil. Cover crop composition and its breakdown rate affect the physical, chemical, and biological properties of soil. To optimize the benefits of plant residue on soil quality improvement, it is critical to synchronize the release of nutrients from residue decomposition with patterns of plant nutrient uptake, which may minimize the loss of available nutrients mainly via. leaching, runoff and erosion (Shi, 2013). Green manure decomposition and subsequent nutrient release depend on residue's quality and quantity as well as soil moisture and temperature, microbial activity and other factors like soil $\mathrm{pH}$, electrical conductivity, etc. (Myers et al., 1994; Thönnissen et al., 2000).

Farmers of Bangladesh have little scope to cultivate green manure crops for soil fertility improvement due to the ever-increasing demand for food and cash crops, using the lands through food and cash crops only. However, the gap period between Boro (winter) rice (January to May) crop harvest and Aman (monsoon rice) transplanting (August) is ca. $60-70$ days (Haque et al., 2001); this period may allow the farmers to raise leguminous green manure crops like dhaincha (Sesbania spp.). Legume crops also fix atmospheric nitrogen through LegumeRhizobium symbiosis and its decomposition has the potentiality to enhance the yield of subsequent crops (Odhiambo, 2010; Chanda and Sarwar, 2017). Dhaincha plants are soft, succulent and readily decomposable in soil within 60 days. The rate of decomposition is very rapid within one to two weeks after incorporation in soil and thereafter declining gradually (Beri et al., 1989; Swarup, 1991). Crops generally require more nutrients at the juvenile period compared to the reproductive period. The decomposed dhaincha plant may provide sufficient amounts of nutrients for plant growth paving the way for the reduction of mineral/artificial fertilizer during the juvenile period. However, information on dhaincha decomposition rate and the available quantity of released nutrients is scanty (Swarup, 1991; Munawar et al., 2011). Therefore, this experiment was carried out to compare the biomass yield potential, biochemical properties, decomposition and nutrients release patterns of different dhaincha genotypes.

\section{MATERIALS AND METHODS}

An experiment was carried out in a medium highland at Field Laboratory of the Department of Crop Botany, Bangladesh Agricultural University, Mymensingh (24 56.11' N, 89 55.54' E) which belongs to Old Brahmaputra Floodplain (Agro-ecological zone; FAO/UNDP, 1988) with non-calcareous dark grey floodplain soil characteristics (Figure 01). According to US Soil Taxonomy, the soil is Aeric Haplaquept under the Order Inceptisols and as per FAO Soil Unit, it is Chromic-Eutric Gleysols. The location has a subtropical humid climate and is characterized by hot and humid summer and cold winter. Six dhaincha accessions from three Sesbania species, viz. S. bispinosa (accession \#05, 71, 77 and 109), S. cannabina (accession \#28) and S. sesban (accession \#81), were used as experimental test crops. Dhaincha crop was grown following standard cultivation procedure viz. seed rate@ $60 \mathrm{~kg} \mathrm{ha}^{-1}$, sowing at 30 April adding a fertilizer dose of $20 \mathrm{~kg} \mathrm{~N}, 10 \mathrm{~kg} \mathrm{P}_{2} \mathrm{O}_{5}, 10 \mathrm{~kg} \mathrm{~K}_{2} \mathrm{O} \mathrm{ha}{ }^{-1}$ from urea, triple superphosphate and muriate of potash, respectively (Chanda et al., 2020). The experiment was replicated thrice and laid out in a randomized complete block design with a unit plot size of $2.5 \mathrm{~m} \times 4.0 \mathrm{~m}$. Both $\mathrm{P}_{2} \mathrm{O}_{5}$ and $\mathrm{K}_{2} \mathrm{O}$ were applied during final land preparation and $\mathrm{N}$ was applied as top dress at 30 days after sowing (DAS). At 60 DAS, twenty plants were randomly sampled to record data on yield and yield contributing descriptors. Plant biomass was recorded by drying fresh samples in an oven at $72 \pm 2{ }^{\circ} \mathrm{C}$ for $72 \mathrm{hrs}$. 

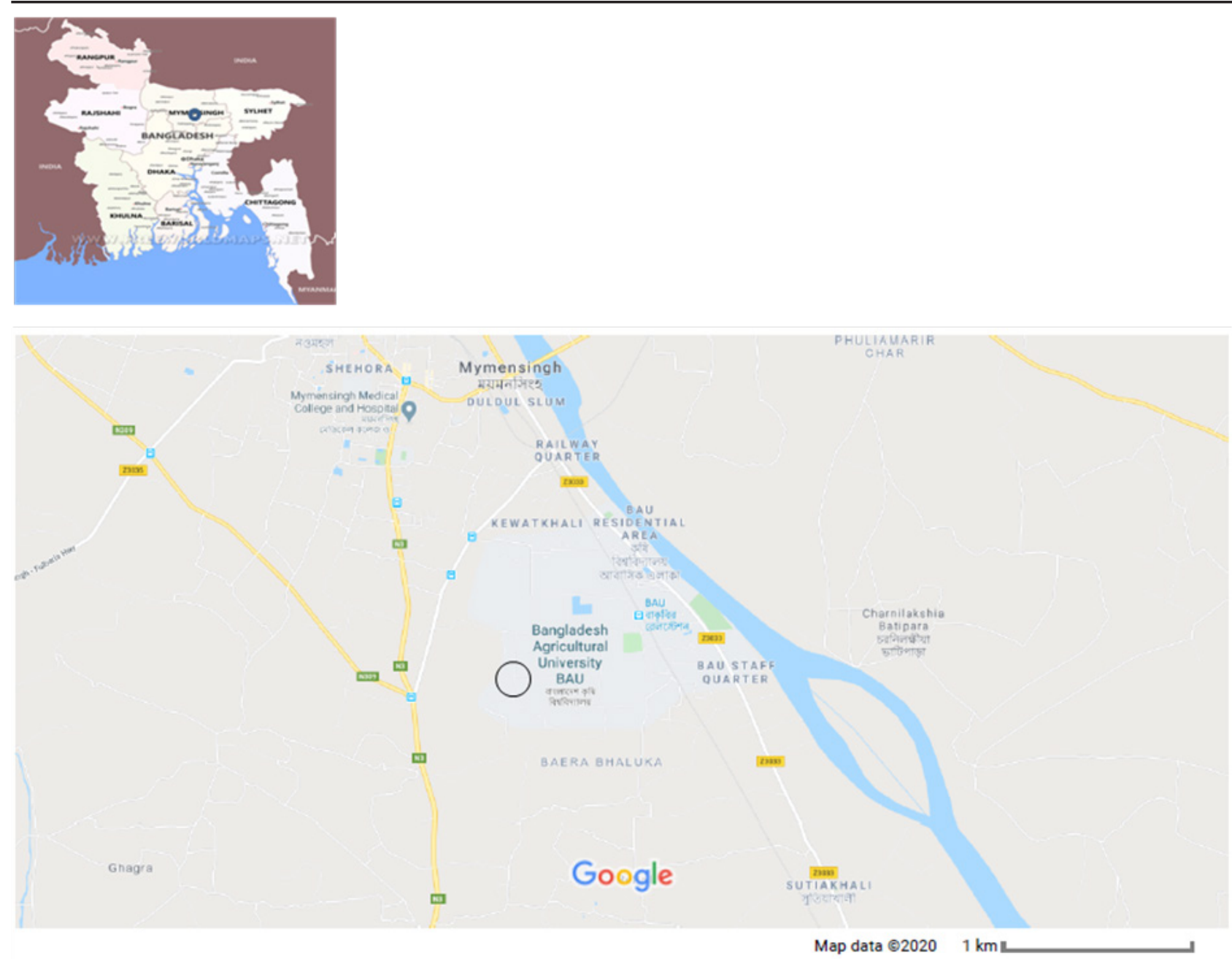

Figure 01: Location map of the experimental site - The Bangladesh Agricultural University circle in Bangladesh (upper) Map; The Field Laboratory circle in Google (lower) Map.

The biochemical composition of dhaincha accessions was determined at the Laboratory of Department of Animal Science, Bangladesh Agricultural University following methods described in Kabir et al. (2018). Plant materials were chopped into pieces of 2-3 $\mathrm{cm}$ sizes by "Hausa" and mixed with the soil by spade up to $15 \mathrm{~cm}$ soil depth. A total of seven soil samples were collected, before dhaincha seed sowing and up to 60 days after incorporation (DAI) of plant materials to soil at 10 days intervals. At each

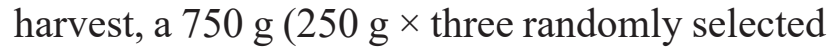
points per plot) of soil sample was collected using an auger from $0-15 \mathrm{~cm}$ depth, composited and homogenized to represent each plot. Any undecomposed crop debris was discarded from the soil sample. Soil samples were air-dried, ground and passed through a $2 \mathrm{~mm}$ sieve and were placed in zip-locked plastic containers until the determination of chemical parameters of soil. Soil sample was analyzed for soil $\mathrm{pH}$ (soil:water was 1:2.5), total nitrogen (Bremner and Mulvaney, 1982), organic matter (Nelson and Sommers, 1982), available P (Olsen and Sommers, 1982 ), available K (Knudsen et al., 1982) and available S (Fox et al., 1964). Collected data were analyzed statistically and mean differences were adjudged by Duncan's Multiple Range Test (Gomez and Gomez, 1984).

\section{RESULTS}

\section{Yield performance of dhaincha accessions}

Dhaincha accessions belong to species $S$. bispinosa (accession \#05, 71, 77 and 109) generally produced higher biomass yield compared to S. cannabina (accession \#28) and $S$. sesban (accession \#81) (Table 01). The 
dhaincha accessions also differed significantly on plant height, base diameter, fresh and dry weight per plant, fresh weight and biomass yield per hectare (Table 01). The tallest plant and widest base diameter $(207.10 \mathrm{~cm}$ and $1.08 \mathrm{~cm}$, respectively) were observed in accession \#71 and the shortest and narrowest $(100.99 \mathrm{~cm}$ and 0.74 $\mathrm{cm}$, respectively) in accession \#81 (Table 01). The highest fresh and dry weight (115.84 and 24.56 g plant $^{-1}$, respectively) were also produced by accession \#71 and the lowest values (58.21 and $10.61 \mathrm{~g} \mathrm{plant}^{-1}$, respectively) in accession \#81 (Table 01). The highest fresh and biomass yield (77.44 and $19.13 \mathrm{t} \mathrm{ha}^{-1}$, respectively) were produced in accession \#71 and it was statistically similar to accession \#77 and 109. On the contrary, accession \#81 produced the lowest fresh and biomass yield (27.29 and $10.24 \mathrm{t} \mathrm{ha}^{-1}$, respectively) (Table 01).

\section{Dry matter and Biochemical composition of dhaincha accessions}

Biochemical composition of different dhaincha genotypes varied considerably (Table 02). The highest dry matter content was found in accession \#71 (92.18\%) and the lowest was in accession \#81 (90.36\%). The ash content varied from $7.63 \%$ in accession \#77 to $10.03 \%$ in accession \#109. The highest crude protein content was found in accession \#71 (18.44\%) and was followed by accession \#81 (18.22\%), accession \#109 (17.39\%), accession \#28 (16.31\%), accession \#77 (15.88\%) and accession \#05 (13.81\%). The crude fibre in different dhaincha accession ranged from $25.57 \%$ observed in accession \#81 to $46.13 \%$ in accession \#28 (Table 02 ).

Table 01: Biomass and yield contributing descriptors of different dhaincha accessions

\begin{tabular}{ccccccc}
\hline Accessions & $\begin{array}{c}\text { Plant height } \\
(\mathrm{cm})\end{array}$ & $\begin{array}{c}\text { Base diameter } \\
(\mathrm{cm})\end{array}$ & $\begin{array}{c}\text { Fresh weight } \\
\left(\mathrm{g} \mathrm{plant}^{-1}\right)\end{array}$ & $\begin{array}{c}\text { Biomass } \\
\text { weight } \\
\left(\mathrm{g} \mathrm{plant}^{-1}\right)\end{array}$ & $\begin{array}{c}\text { Fresh yield } \\
\left(\mathrm{t} \mathrm{ha}^{-1}\right)\end{array}$ & $\begin{array}{c}\text { Biomass yield } \\
\left(\mathrm{t} \mathrm{ha}^{-1}\right)\end{array}$ \\
\hline Acc. \#05 & $193.20 \mathrm{ab}$ & $0.917 \mathrm{a}-\mathrm{c}$ & $97.35 \mathrm{bc}$ & $19.59 \mathrm{bc}$ & $70.20 \mathrm{ab}$ & $15.20 \mathrm{bc}$ \\
Acc. \#28 & $177.69 \mathrm{bc}$ & $0.837 \mathrm{bc}$ & $82.37 \mathrm{c}$ & $16.69 \mathrm{c}$ & $60.13 \mathrm{c}$ & $13.70 \mathrm{~cd}$ \\
Acc. \#71 & $207.10 \mathrm{a}$ & $1.076 \mathrm{a}$ & $115.84 \mathrm{a}$ & $24.56 \mathrm{a}$ & $77.44 \mathrm{a}$ & $19.13 \mathrm{a}$ \\
Acc. \#77 & $192.56 \mathrm{ab}$ & $0.960 \mathrm{ab}$ & $107.38 \mathrm{ab}$ & $21.92 \mathrm{ab}$ & $71.74 \mathrm{ab}$ & $16.85 \mathrm{a}-\mathrm{c}$ \\
Acc. \#81 & $100.99 \mathrm{~d}$ & $0.740 \mathrm{c}$ & $58.21 \mathrm{~d}$ & $10.61 \mathrm{~d}$ & $27.29 \mathrm{~d}$ & $10.42 \mathrm{~d}$ \\
Acc. \#109 & $180.00 \mathrm{~b}$ & $0.853 \mathrm{bc}$ & $87.33 \mathrm{c}$ & $18.33 \mathrm{bc}$ & $68.52 \mathrm{~b}$ & $17.26 \mathrm{ab}$ \\
$\mathrm{CV}$ & 8.47 & 12.44 & 9.97 & 13.00 & 7.08 & 12.07 \\
$\mathrm{~S}_{\mathrm{E}}$ & 27.05 & 0.20 & 16.57 & 4.40 & 8.06 & 3.39 \\
\hline
\end{tabular}

Table 02: $\quad$ Proximate analysis of dhaincha accessions showing mean and standard deviation.

\begin{tabular}{ccccc}
\hline Accessions & Dry matter (\%) & Ash (\%) & Crude Protein (\%) & Crude Fibre (\%) \\
\hline Acc. \#05 & $91.31 \pm 2.55$ & $8.34 \pm 0.52$ & $13.81 \pm 2.95$ & $30.84 \pm 1.38$ \\
Acc. \#28 & $90.67 \pm 1.14$ & $8.00 \pm 1.54$ & $16.31 \pm 1.77$ & $46.13 \pm 0.84$ \\
Acc. \#71 & $92.18 \pm 3.63$ & $9.23 \pm 2.91$ & $18.44 \pm 1.48$ & $30.76 \pm 2.33$ \\
Acc. \#77 & $90.83 \pm 1.80$ & $7.63 \pm 0.52$ & $15.88 \pm 1.20$ & $26.88 \pm 1.64$ \\
Acc. \#81 & $90.36 \pm 0.71$ & $9.03 \pm 0.86$ & $18.22 \pm 0.94$ & $25.57 \pm 1.68$ \\
Acc. \#109 & $90.84 \pm 1.40$ & $10.03 \pm 1.68$ & $17.39 \pm 1.03$ & $27.31 \pm 1.09$ \\
\hline
\end{tabular}




\section{Soil chemical and nutritional properties}

Dhaincha green manure incorporation has significant residual effects (Chanda and Sarwar, 2017) and considerable influence on the soil properties (Rahman et al., 2013). The incorporation of dhaincha remarkably increased soil $\mathrm{pH}, \mathrm{OM}, \mathrm{N}, \mathrm{P}, \mathrm{K}$ and $\mathrm{S}$ compared to initial soil nutrients status. All the parameters studied increased with the period of time and reached a peak at $50 \mathrm{DAI}$ and declined thereafter except soil pH, K and S (Figures 2-7).

Soil pH: After incorporation of dhaincha accessions, the soil $\mathrm{pH}$ has increased by $25.37 \%$ to $26.80 \%$ against its initial $\mathrm{pH}$ of 5.82 (Figure 02). The highest soil $\mathrm{pH}$ (7.95) was found in accession \#71 at $60 \mathrm{DAI}$ and the lowest soil pH (6.94) in accession \#28 at 10 DAI.

Soil organic matter: Initial soil organic matter was $1.53 \%$. The maximum soil organic matter $(2.40 \%)$ was found in accessions \#71 and \#77 at 50 DAI and the minimum (1.18\%) in accession \#81 at 60 DAI (Figure 03).

Total nitrogen: The initial soil total nitrogen content was $0.09 \%$. The highest total $\mathrm{N}$ content

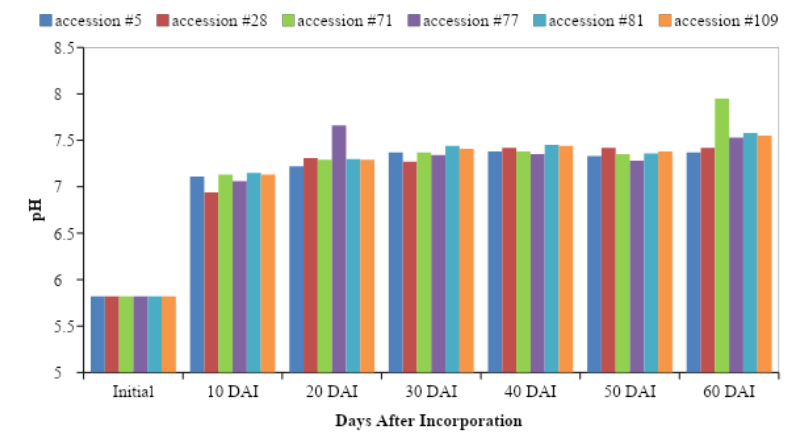

Figure 02: Soil $\mathrm{pH}$ at different days after incorporation of six dhaincha accessions.

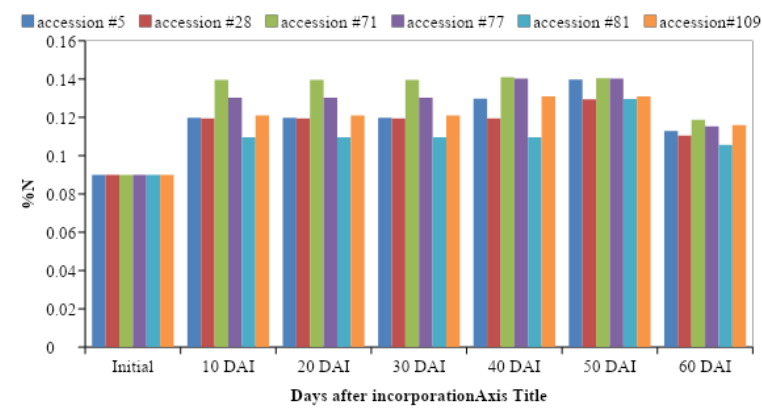

Figure 04: Total nitrogen (\%) at different days after incorporation of six dhaincha accessions was noted due to the incorporation of dhaincha accessions \#71, 77 and 05 (0.14\%) and the lowest total $\mathrm{N}$ in treatments with the incorporation of dhaincha accession \#109, 81 and $28(0.13 \%)$ at 50 DAI (Figure 04).

Available phosphorus: The maximum value of available phosphorus (10.88 ppm) was observed due to the incorporation of dhaincha accession $\# 05$ and the minimum (8.27 ppm) by accession \#28 at $50 \mathrm{DAI}$, from the initial value $3.6 \mathrm{ppm}$ (Figure 05).

Available potassium: The amount of potassium in soil reached to the peak $(0.27 \mathrm{meq} / 100 \mathrm{~g})$ at 40 and 50 DAI in accession \#5 (Figure 06) and the lowest level was $0.19 \mathrm{meq} / 100 \mathrm{~g}$ in accession \#81. The initial available soil potassium level was $0.19 \mathrm{meq} / 100 \mathrm{~g}$.

Available sulfur: The sulfur content in soil reached to a maximum at 20 DAI of dhaincha green manure (Figure 07). At the beginning, soil sulfur value was $2.51 \mathrm{ppm}$. The highest levels of sulfur $(5.25 \mathrm{ppm})$ was noted due to the incorporation of the biomass produced by accession \#05 and the lowest value (2.64 ppm) in accession \#109 at 20 DAI.

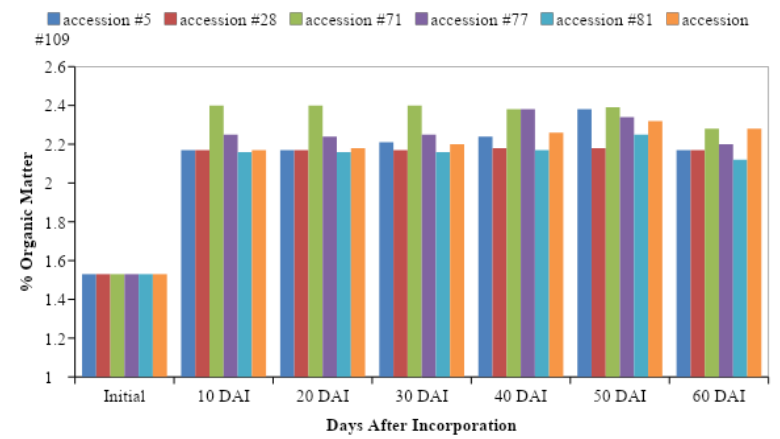

Figure 03: Organic Matter (\%) at different days after incorporation of six dhaincha accessions

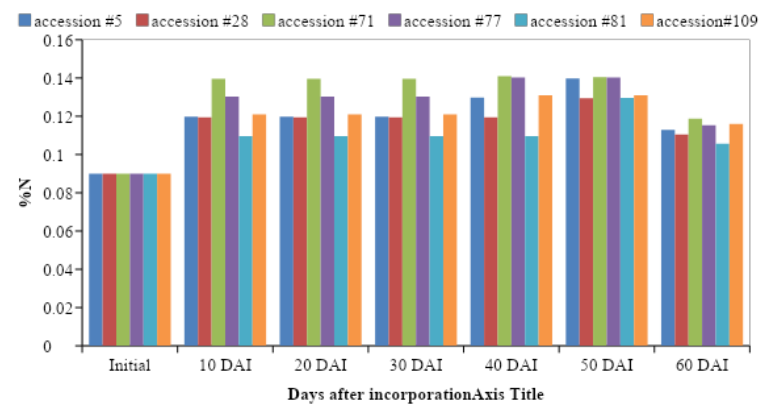

Figure 05: Available phosphorus at different days after incorporation of six dhaincha accessions 


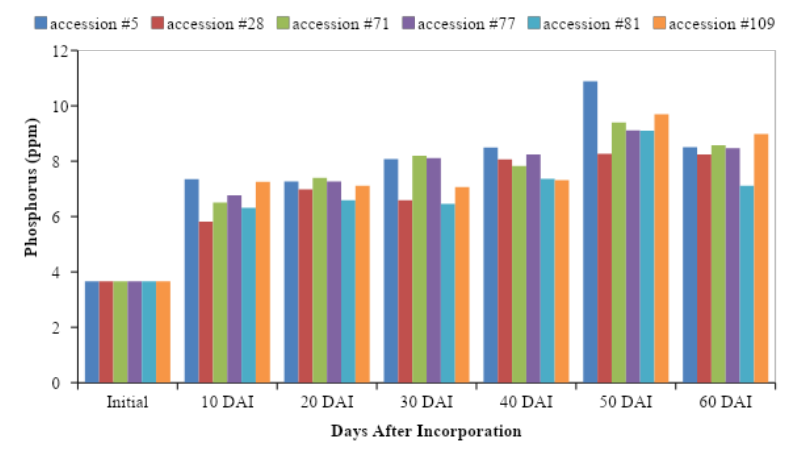

Figure 06: Available potassium at different days after incorporation of six dhaincha accessions

\section{DISCUSSION}

\section{Biomass yield performance of dhaincha accessions}

Plant height, base diameter, fresh weight and biomass ( $\mathrm{g}$ plant $\left.{ }^{-1}\right)$, and fresh and biomass yield $\left(\mathrm{t} \mathrm{ha}^{-1}\right)$ of different dhaincha accessions were influenced by plant population densities, sowing time and fertilizer doses (Chanda et al., 2020). The biomass yield was directly correlated to plant height and base diameter of the respective accessions (Table 01). The significant differences in yield and yield contributing descriptors might be due to the variation in the genetic makeup of the respective accessions (Sarwar et al., 2015). The maximum biomass yield was obtained from accession \#71 followed by accession 109, 77, 05, 28 and it was nearly double the lowest biomass producer accession \#81 (Table 01). Naidu et al. (2017) also stated that crop growth and yield of soybean varied widely in different genotypes.

\section{Biochemical composition of dhaincha accessions}

Variation in proximate composition i.e., ash, crude protein and crude fibre among the dhaincha accessions were significant (Table 02). These components were contoured to increase the soil nutrients status as well as fodder quantity for livestock (Kabir et al., 2018). About eight weeks old dhaincha plants had $3 \% \mathrm{~N}$ in addition to $\mathrm{K}$, $\mathrm{Ca}, \mathrm{Mg}, \mathrm{P}, \mathrm{S}$ and micronutrients (Bhuiyan et al., 1988). Soil chemical properties were found to improve by adding biomass from dhaincha genotypes in soil. Rowell (2005) reported that

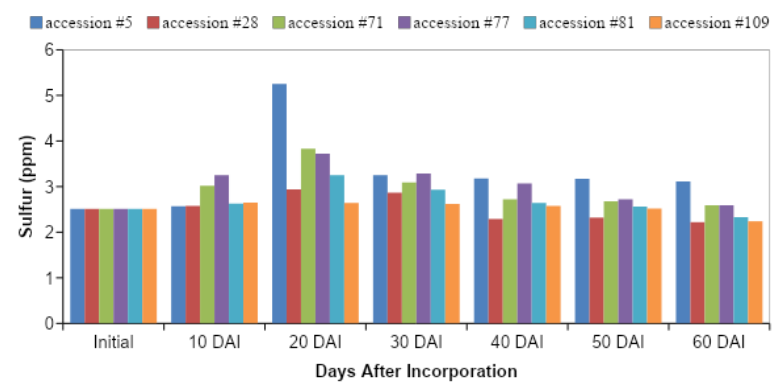

Figure 07: Available sulfur at different days after incorporation of six dhaincha accessions

wood and plant cellulose act as reinforcement, hemicelluloses and pectin as bonding, lignin for stiffness and wax for use as coating. Based on the presence of crude fibre, accession \#28 (S. cannabina) was distinctly different from the others (Table 02). Sarkar et al. (2017) reported that $S$. bispinosa contained klasonlignin (20.91$26.87 \%)$, pentosan (15.83-18.81\%), holocellulose (65.98-74.55\%), $\alpha$-cellulose (39.50$43.70 \%)$ and ash (1.03-1.91\%). On the other hand, $S$. cannabina contained klasonlignin (22.91-23.45\%), pentosan (16.02-17.87\%), holo-cellulose $\quad(66.10-75.47 \%), \quad \alpha$-cellulose (39.74-40.88\%) and ash (1.24-1.67\%). However, S. sesban had klasonlignin (21.87-22.07\%), pentosan (16.20-18.33\%), holo-cellulose (69.77$71.20 \%), \alpha$-cellulose (40.42-42.80\%) and ash (1.67-2.15\%). Raja et al. (2016) reported that S. rostrata fibres showed cellulose content of $64.36 \%$, hemicelluloses $11.25 \%$, lignin $17.19 \%$ and ash $1.45 \%$. The biochemical properties of green biomass play an important role in the decomposition process and nutrient release from an organic source. The $\mathrm{C}: \mathrm{N}$ ratio of plant biomass dominates the decomposition rate within a single climate zone (He et al., 2016; Thönnissen et al., 2000). The water-soluble fractions of green manure get metabolized early followed by cellulose and hemicellulose. Lignin is the most resistant component to decompose in soil (Alexander, 1977). Dhaincha accessions used in this study had variable amounts of crude protein and crude fibre; therefore, their decomposition and nutrient release pattern were different at different sampling times. 


\section{Soil chemical and nutritional properties}

Decomposition of dhaincha added organic matter and different nutrient elements in the soil. The rate of decomposition of organic residues depends upon the physical soil environment (location, temperature, moisture, oxygen, compaction, clay content), chemical composition of residues ( $\mathrm{C}: \mathrm{N}, \mathrm{C}: \mathrm{P}, \mathrm{C}: \mathrm{S}$, lignin, celleulose and hemicellulose content) and microbiological community structure of the soil (Thönnissen et al., 2000; Robertson and Paul, 2000; Bastian et al., 2009; Berg et al., 2007; Zhu et al., 2013). The amounts of organic matter as well as total $\mathrm{N}$, available $\mathrm{P}, \mathrm{K}$ and $\mathrm{S}$ in soil increased up to 50 days after the incorporation of Sesbania accessions in soil; thereafter, it declined or tended to be constant (Figs 2-7). Rahman et al. (2013) stated that mineralization pattern from decomposed green manure was initially very low followed by a faster rate up to 5-7 weeks and thereafter, declined with time. The generally faster decay of N-rich accession suggests that green manure decay rates would increase when $\mathrm{N}$ contents were increased, or would decrease if the $\mathrm{N}$ content declined (Shi, 2013). Decomposition rate depends on the amount of hemicelluloses, cellulose and lignin in the accessions. The maximum decomposition time varied among species or within a species (Berg et al., 1996). In the initial stages- leaf, bark and other soft parts break down and these parts contain small soluble carbon molecules like starches and amino acids which are easy to break down. However, more recalcitrant molecules like lignin consist of complex molecules; consequently, it takes a longer time of decomposition and thus nutrients reserve in soil and release latter (Berg et al., 2007). At 50 days after incorporation, the available nutrients were gradually declined possibly due to leaching of nutrients or fixation in soil. Researchers suggested that decomposed soil nutrients can be lost to the environment viz. erosion, leaching, decomposition, volatilization and plant uptake (Blum, 1997; Rahman et al., 2013; Huda et al., 2016).

One ton of dhaincha biomass application to soil added approximately $33 \mathrm{~kg} \mathrm{~N}, 1 \mathrm{~kg} \mathrm{P}, 14 \mathrm{~kg} \mathrm{~K}, 14$ $\mathrm{kg} \mathrm{Ca}, 16 \mathrm{~kg} \mathrm{Mg}$ and $2 \mathrm{~kg} \mathrm{~S}$ (Bhuiyan et al., 1988). Thönnissen et al. (2000) reported that peak $\mathrm{N}$ release occurred after 5 to 8-week decomposition of green manure and declined thereafter. Many researchers observed that the decomposition rate become slow or declined after a certain period (Neely et al., 1991; Grant et al., 1993; Odhiambo, 2010). They stated that microbial activity is controlled by soil temperature, oxygen, substrate availability and microorganism activity as well $\mathrm{C}: \mathrm{N}$ ratio. Munawar et al. (2011) found that the initial decomposition process of Sesbania plant is high and decomposable substance is released rapidly. Firstly, celluloses are decomposed and it is used by microorganisms, more recalcitrant as lignin and tannin; consequently, their decomposition rates decrease with times (Dux et al., 2006). The mineralization rate of incorporated green manure was higher during the first week of its incorporation (Dinesh and Dubey, 1998) and extended till 20 days; thereafter, the process slowed down (Clement et al., 1998). Beri et al. (1989) reported that $S$. aculeata (presently $S$. bispinosa) was mineralized $40 \% \mathrm{C}$ and $80 \% \mathrm{~N}$ in the first 10 days of incorporation in wetland field condition. The $\mathrm{N}$ release got its peak during 35 days after incorporation (Dey and Jain, 1996; Thönnissen et al., 2000).

Green manure added as dhaincha biomass increased organic matter, total $\mathrm{N}$, available $\mathrm{P}$, $\mathrm{K}$ and $\mathrm{S}$ in post-harvest soil (Figs 2-7). The higher the soil $\mathrm{N}$ supply, the more legumes derive $\mathrm{N}$ from soil rather than from biological $\mathrm{N}_{2}$ fixation (Thönnissen et al., 2000). The results are in agreement with the findings of Ehsan et al. (2014) who stated that physical and chemical environments of soil improved with the incorporation of green manure and enhanced soil nutrients status. The enrichment of soil nutrients could be attributed to the dhaincha incorporation. The nutrients status of soil would be increased after continuous cultivation of green manure like Sesbania crop and their incorporation in soil. The incorporation of $S$. sesban as mulch (13 t ha ${ }^{-1} \mathrm{DM}$ ) improved the soil nutrient status and residual effects lasted up to 3 years (Onim et al., 1990). The poor soil may become fertile after 10-12 years of continuous cultivation and incorporation of Sesbania green manure (Carroll and Somerville, 2009). 


\section{CONCLUSION}

It is evident from the study that the status of soil organic matter, total $\mathrm{N}$, available $\mathrm{P}, \mathrm{K}$ and $\mathrm{S}$ generally increased up to $50 \mathrm{DAI}$ and then declined or became static for some period. Accession \#71 produced the highest biomass and had maximum crude protein and minerals in the form of ash; it had increased the maximum amount of organic matter in the soil. Therefore, accession \#71 could be distributed for regional trials to release as a recommended cultivar.

\section{ACKNOWLEDGEMENTS}

We acknowledge the financial support of the Ministry of Science and Technology, Government of the People's Republic of Bangladesh.

\section{REFERENCES}

Alexander, M. (1977). Introduction to Soil Microbiology. John Wiley and Sons, New York.

Ali, M.M., Saheed, S.M., Kubota, D., Masunaga, T., and Wakatsuki, T. (1997). Soil degradation during the period 1967-1995 in Bangladesh. Soil Science and Plant Nutrition 43: 863-878. doi: 10.1080/00380768.1997.10414653

Bastian, F., Bouziri, L., Nicolardot, B., and Ranjard, L. (2009). Impact of wheat straw decomposition on successional patterns of soil microbial community structure. Soil Biology and Biochemistry 41: 262-275. doi: 10.1016/j.soilbio.2008.10.024

Berg, B., Ekbohm, G., Johansson, M., McClaugherty, C., Rutlgliano, F., and de Santo, A.V. (1996). Maximum decomposition limits of forest litter types: a synthesis. Canadian Journal of Botany 74: 659-672. doi: 10.1139/b96-084

Berg, B., Steffen, K.T., and McClaugherty, C. (2007). Litter decomposition rate is dependent on litter Mn concentrations. Biogeochemistry 82: 29-39. doi: 10.1007/s10533-006-9050-6

Beri, V., Meelu, O.P., and Khind, C.S. (1989). Studies on Sesbania aculeata Pers. as green manure for $\mathrm{N}$-accumulation and substitution of fertilizer-N in wet land rice. Tropical Agriculture (Trinidad) 66: 209-212.

Bhuiyan, N.I., Zaman, S.K., and Panaullah, G.M. (1988). Dhaincha green manure: A potential nitrogen source for rain-fed lowland rice. Proceedings of Workshop, International Rice Research Institute, Philippines. p. 108.

Blum, W.H. (1997). Basic concepts: Degradation, resilience, and rehabilitation. In: Methods for assessment of soil degradation. Lal, R., Blum, W.H., Valentine, C., and Stewart, B.A., eds., Boca Raton: CRC Press. pp. 1-16.

Bremner, J.M., and Mulvaney, C.S. (1982). Nitrogen-Total. In: Methods of Soil Analysis, Part 2. Page, A.L., Miller, R.H., and Keeney, D.R., eds., ASA and SSSA, Madison, WI, USA, pp. 595624.

Carroll, A., and Somerville, C. (2009). Cellulosic biofuels. Annual Review of Plant Biology 60: 165182. doi: 10.1146/annurev.arplant.043008.092125 
Chanda, S.C., and Sarwar, A.K.M. Golam. (2017). Status of dhaincha incorporated soil after rice harvest in (Boro) rice-dhaincha-rice (T. Aman) cropping pattern. Cercetări Agronomice în Moldova 172: 75-84. doi: 10.1515/cerce-2017-0037

Chanda, S.C., Razzak, M.A., Hossain, M.A., and Sarwar, A.K.M. Golam. (2020). Biomass yield enhancement of dhaincha (Sesbania species) through cultural practices. Cercetări Agronomice in Moldova 182: 160-176. doi: 10.46909/cerce-2020-014

Clement, A., Ladha, J.K., and Chalifour, F.P. (1998). Nitrogen dynamics of various green manure species and the relationship to lowland rice production. Agronomy Journal 90: 149-154. doi: 10.2134/agronj1998.00021962009000020005x

Dey, P., and Jain, J.M. (1996). Nitrogen mineralization from enriched green manures as influenced by water management practices. Journal of the Indian Society of Soil Science 44: 633-638.

Dinesh, R., and Dubey, R.P. (1998). Nitrogen mineralization rates and kinetics in soils freshly amended with green manures. Journal of Agronomy and Crop Science 181: 49-53. doi: 10.1111/j.1439037X.1998.tb00397.x

Dux, J., Norgrove, L., Hauser, S., Wick, B., and Kuhne, R. (2006). Plant leaf residue decomposition, nutrient release, and soil enzyme activity. Conf. Int. Agric. Res. Dev., Univ. Bonn, Germany. October 11-13, 2006.

Ehsan, S., Niaz, A., Saleen, I., and Mehmood, K. (2014). Substitution of major nutrient requirement of rice-wheat cropping system through Sesbania green manuring. Sciatica Agricola 8: 99-102.

FAO/UNDP. (1988). Land Resources Appraisal of Bangladesh for Agricultural Development, Vol 2, Agroecological Regions of Bangladesh, Rome, pp. 1-570.

Fox, R.L, Olson, R.A. and Rhoades, H.F. (1964). Evaluating the sulfur status of soils by plants and soil tests. Soil Science Society of America Journal 28: 243-246. doi: 10.2136/ sssaj1964.03615995002800020034x

Gomez, K.A., and Gomez, A.A. (1984). Statistical Procedure for Agricultural Research. International Rice Research Institute, John Wiley and Sons, New York, USA.

Grant, R.F., Juma, N.G., and McGill, W.B. (1993). Simulation of carbon and nitrogen transformations in soil: Mineralization. Soil Biology and Biochemistry 25: 1317-1329. doi: 10.1016/00380717(93)90046-E

Haque, M.F., Razzaque, M.A., and Akhteruzzaman, A. (eds). (2001). A Compendium: Packages of Technologies. A handbook for Farming System Development. FSRD program, Bangladesh Agricultural Research Council, Dhaka, Bangladesh. p: 12.

He, P., Wan, S.-Z., Fang, X.-M., Wang, F.-C., and Chen, F.-S. (2016). Exogenous nutrients and carbon resource change the responses of soil organic matter decomposition and nitrogen immobilization to nitrogen deposition. Scientific Reports 6: 23717. doi: 10.1038/srep23717

Huda, A., Gaihre, Y.K., Islam, M.R., Singh, U., Islam, M.R., Sanabria, J., Satter, M.A., Afroz, H., Halder, A., and Jahiruddin, M. (2016). Floodwater ammonium, nitrogen use efficiency and rice yields with fertilizer deep placement and alternate wetting and drying under triple rice cropping systems. Nutrient Cycling in Agroecosystems 104: 53-66. doi: 10.1007/s10705-015-9758-6 
Kabir, A.K.M.A., Moniruzzaman, M., Gulshan, Z., Rahman, A.B.M.M., and Sarwar, A.K.M. Golam. (2018). Biomass yield, chemical content and in vitro gas production of different dhaincha (Sesbania spp.) accessions from Bangladesh. Indian Journal of Animal Nutrition 35: 397-402. doi: 10.5958/2231-6744.2018.00060.9

Knudsen, D., Peterson, G.A., and Pratt, P.F. (1982). Lithium, sodium and potassium. In: Methods of Soil Analysis, Part 2. Page, A.L., Miller, R.H. and Keeney, D.R., eds., ASA and SSSA, Madison, WI, USA, pp. 225-245.

Munawar, A., Indarmawan, and Suhartoyo, H. (2011). Litter production and decomposition rate in the reclaimed mined land under Albizia and Sesbania stands and their effects on some soil chemical properties. Journal of Tropical Soils 16: 1-6. doi: 10.5400/jts.2011.16.1

Myers, R.J.K., Palm, C.A., Cuevas, E., Gunatilleke, I.U.N., and Brossad, M. (1994). The synchronization of nutrient mineralization and plant nutrient demand. In: The Biological Management of Tropical Soil Fertility. Woomer, P.L., and Swift, M.J., eds., Wiley-Sayce Publ., Chichester, UK. pp. 81-116.

Naidu, C.R., Reddy, G.K., Sumathi, V., and Reddy, P.V.M. (2017). Response of soybean varieties to different sowing times. Journal of Pharmacognosy and Phytochemistry 6: 1092-1095.

Neely, C.L., Beare, M.H., Hargrove, W.L., and Coleman, D.C. (1991). Relationship between fungal and bacterial substrate-induced respiration (SIR), biomass and plant residue decomposition. Soil Biology and Biochemistry 23: 947-954. doi: 10.1016/0038-0717(91)90175-J

Nelson, D.W., and Sommer, L.E. (1982). Total Carbon, Organic Carbon and Organic Matter. In: Methods of Soil Analysis, Part 2. Page, A.L., Miller, R.H., and Keeney, D.R. eds., ASA and SSSA, Madison, WI, USA, pp. 539-579.

Odhiambo, J.J.O. (2010). Decomposition and nitrogen release by green manure legume residues in different soil types. African Journal of Agricultural Research 5: 90-96. doi: 10.5897/ AJAR09.489

Olsen S.R. and Sommer, L.E. (1982). Phosphorus. In: Methods of Soil Analysis. Part 2. Page, A.L., Miller, R.H., and Keeney, D.R., eds., ASA and SSSA, Madison, WI, USA, pp. 403-430.

Onim, J.F.M., Mathuva, M., Otieno, K., and Fitzhugh, H.A. (1990). Soil fertility changes and response of maize and beans to green manures of Leucaena, Sesbania and Pigeon pea. Agroforestry Systems 12: 197-215. doi: 10.1007/BF00123474

Rahman, M.H., Islam, M.R., Jahiruddin, M., Puteh, A.B., and Mondal, M.M.A. (2013). Influence of organic matter on nitrogen mineralization pattern in soils under different moisture regimes. International Journal of Agriculture and Biology 15: 55-61.

Raja, K., Senthilkumar, P., Nallakumarasamy, G., and Natarajan, T. (2016). Characterization of natural fiber extracted from Sesbania rostrata: An alternative potential for synthetic fibers. Journal of Advances in Chemistry 12: 4930-4937. doi: 10.24297/jac.v12i16.840

Robertson, G.P., and Paul, E.A. (2000). Decomposition and soil organic matter dynamics. In: Methods in Ecosystem Science. Osvaldo, E.S., Jackson, R.B., Mooney H.A., and Hopwarth, R., eds., Springer Verlag, New York, USA, pp. 104-116.

Rowell, R.M. (2005). Handbook of Wood Chemistry and Wood Composites. CRC Press. 
Sarker, M., Sutradhar, S., Sarwar, A.K.M. Golam, Uddin, M.N., Chanda, S.C., and Jahan, MS. 2017. Variation of chemical characteristics and pulpability of dhaincha (Sesbania bispinosa) on location. Journal of Bioresources and Bioproducts 2: 24-29. doi: 10.21967/jbb.v2i1.128

Sarwar, A.K.M. Golam, Islam, A., and Jahan, S. (2015). Characterization of dhaincha accessions based on morphological descriptors and biomass production. Journal of the Bangladesh Agricultural University 13: 55-60. doi: 10.3329/jbau.v13i1.28713

Shi, J. (2013). Decomposition and Nutrient Release of Different Cover Crops in Organic Farm Systems. MS thesis, University of Nebraska - Lincoln, New Zealand. pp. 1-75. http://digitalcommons. unl.edu/natresdiss/75

Swarup, A. (1991). Effect of Sesbania bispinosa decomposition time and sodality on rice yield. AGRIS Agricultural Information Management Standards 13: 28-29.

Swarup, A. (1998). Emerging soil fertility management issues for sustainable crop productivity in irrigated systems. In: Proceedings of a National Workshop on Long-term Soil Fertility Management through Integrated Plant Nutrient Supply. Swarup, A, Reddy, D.D., and Prasad, R.N., eds, Indian Institute of Soil Science, Bhopal, India. pp. 54-68.

Thonnissen, C., Midmore, D.J., Ladha, J.K., Olk, D.C., and Schmidhalter, U. (2000). Legume decomposition and nitrogen release when applied as green manures to tropical vegetable production systems. Agronomy Journal 92: 253-260. doi: 10.2134/agronj2000.922253x

Zahid, A.M., Hossain, M.B., Halim, M.A., Hossain, M.A., and Shahreen, F. (2011). Organic matter and plant nutrient depletion in major soil series in the High Ganges River Floodplain. International Journal of Sustainable Agricultural Technology 7(10): 30-37.

Zhu, T.B., Zhang, J.B., Yang, W.Y., and Cai, Z.C. 2013. Effects of organic material amendment and water content on $\mathrm{NO}, \mathrm{N}_{2} \mathrm{O}$, and $\mathrm{N}_{2}$ emissions in a nitrate-rich vegetable soil. Biology and Fertility of Soils 49: 153-163. doi:10.1007/s00374-012-0711-4 